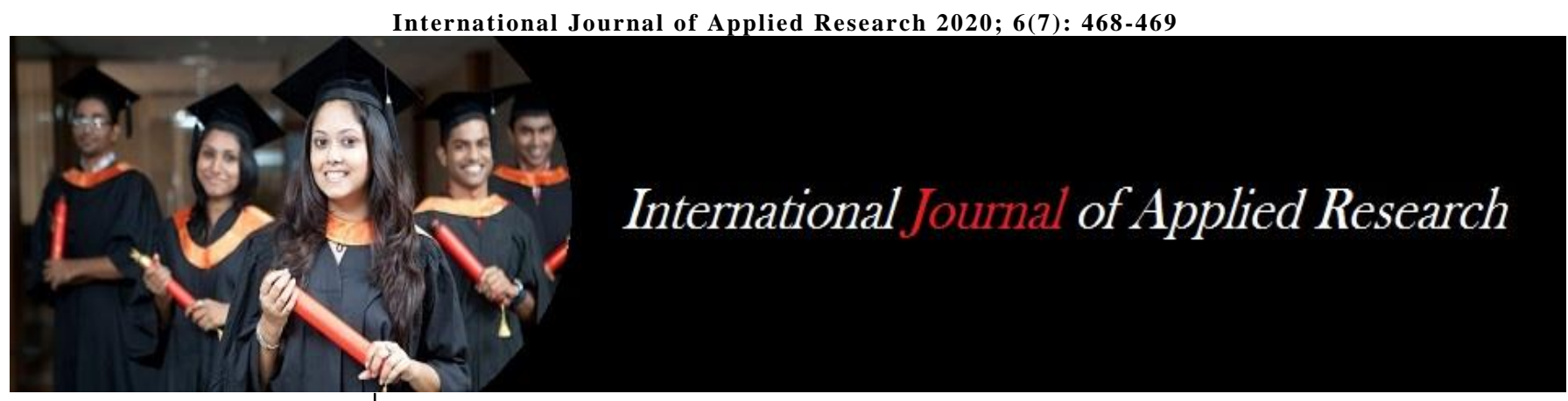

ISSN Print: 2394-7500

ISSN Online: 2394-5869

Impact Factor: 5.2

IJAR 2020; 6(7): 468-469

www.allresearchjournal.com

Received: 01-05-2020

Accepted: 03-06-2020

Anshuman Mandal

Assistant Professor, North

Orissa University, Baripada,

Odisha, India
Corresponding Author:

Anshuman Mandal

Assistant Professor, North

Orissa University, Baripada,

Odisha, India

\title{
Impact of home environment on the academic achievement of tribal students
}

\section{Anshuman Mandal}

\section{Abstract}

The purpose of the present paper is to find out the relationship between home environment and academic achievement among tribal elementary school students. The sample consisted of 100 tribal studnets studying in elementary classes of different schools of Mayurbhanj disttric of Odisha. Result provided evidence that home environment had significant impact on the academic achievement of tribal. It was also found that the students those were more academically achievers had better home environment than their less achievers counterparts. It was also suggested by findings that conducive home environment has significant effect in developing academic achievement of tribal students.

Keywords: Home environment, academic achievement and tribal students

\section{Introduction}

Home is the foundation of all social organizations. It has an everlasting influence on the behavior and personality of its members especially children. Family is the original social institutions from which all other institutions developed. Family is group of interacting personalities, each of which has a definite role and status. It is the place where we learn our first lesson of living together, working together, working in cooperation, helping each other learning lesson of mutual help and adjustment. Education of the child is not the exclusive responsibility of the school. Parents can and should play an important role in shaping and building the career of their children (Sharma, 2011) ${ }^{[9]}$. One of the socially deprived categories of student are the tribal children in odisha. The Tribal children also need to increase motivation, learn skills and have healthy behavioral habits positively reinforced. Tribal children are influenced by the several factors of home environment like academic peroformance also. Conducive home environment has significant effect in developing scholastic achievement of visually impaired students (Mandlakayise \& Manda, 1997) ${ }^{[6]}$. A tribal child is absolutely dependent upon for his food, clothing, medicine and others similar aspects on home. The sociao-econmic status of the children depnds on their vocational insterest (Parua and Sohta, 2010) ${ }^{[8]}$

There must be a harmonious relation between academic achievement \& home environment of tribal children. Parents who are caring for tribal children may need support, information or advice specifically to the academic achievements of the children.

The need to study the effect of home environment on the academic achievements of the tribal children is more important. The present research work is a right endeavor to find out the impact of home environment on the academic achievement of tribal children.

The purpose of the study is to determine the relationship between home environment and academic achievement of tribal students.

\section{Methodology}

The present study was a descriptive survey type of research. A sample of 100 tribal students studying different schools class from V to VIII of Mayurbhanj distric of haryana constituted of the sample. Purposive sampling technique was used to draw the sample from the schools. Statistical techniques like Mean, S.D, t-ratio and Product moment of coefficient of correlation were used for analyzing the data. Home Environment Inventory (HEI) prepared by Mishra was used. Academic results of the students were used for their academic achievements. 


\section{Analysis Procedure}

Table 1: Coefficient of correlation between home environment and academic achievement of tribal students

\begin{tabular}{|c|c|c|c|c|}
\hline & $\mathbf{N}$ & Df & $\begin{array}{c}\text { Coefficient of } \\
\text { correlation }\end{array}$ & $\begin{array}{c}\text { Level of } \\
\text { significance }\end{array}$ \\
\cline { 1 - 4 } Home Environment & \multirow{2}{*}{100} & 98 & .58 & .01 \\
\hline Academic Achievement & & 98 & .01 \\
\hline
\end{tabular}

Table Value of $98 \mathrm{df}$ at. 05 level =. 195 and. 01 level=.254 It is revealed from the table- 1 that the coefficient of correlation between home environment and academic achievement of tribal students is. 58 which is significant at. 01 level of significance. That means there is significant positive relationship between home environment and academic achievements of tribal students. It implies that home environment depends on academic achievements of the students.

Table 2: Coefficient of variables correlation between home environment (dimension wise) and academic achievement of tribal secondary students

\begin{tabular}{|c|c|c|c|}
\hline $\begin{array}{c}\text { Sr. } \\
\text { no }\end{array}$ & Dimension & $\begin{array}{c}\text { Co-efficient of } \\
\text { correlation }\end{array}$ & $\begin{array}{c}\text { Level of } \\
\text { significant }\end{array}$ \\
\hline 1 & Control & .43 & .01 \\
\hline 2 & Protectiveness & .47 & .01 \\
\hline 3 & Punishment & .48 & .01 \\
\hline 4 & Conformity & .49 & .01 \\
\hline 5 & Social isolation & .42 & .01 \\
\hline 6 & Reward & .41 & .01 \\
\hline 7 & Deprivation of privileges & .43 & .01 \\
\hline 8 & Nurturance & .39 & .01 \\
\hline 9 & Rejection & .42 & .01 \\
\hline 10 & Permissiveness & .47 & .01 \\
\hline
\end{tabular}

T.V of $98 \mathrm{df}$ at. 05 level $=.195$ and at.01 level $=.254$

It is shown from the Table-2 that the coefficient of correlation between the dimensions Control (C), Protectiveness (P), Punishment (PU), Conformity $(\mathrm{CF})$, Social Isolation (SI), Reward (R), Deprivation of Privileges (DOP), Nurturance (N), Rejection (RE), Permissiveness (PMS) of Home Environment and academic achievement of tribal students is. 43, 47, 48, 49, 42, 42, 43, 51, 42, 47 respectively. Above mentioned all the dimensions are significant at. 01 level of significance. That means there is significant positive relationship between all the dimensions of Home Environment and academic achievement of tribal students.

Table 3: Significance of difference between high and low academically achiever students on Home Environment.

\begin{tabular}{|c|c|c|c|c|c|c|c|}
\hline Variables & Groups & N & Mean & S.D & SED & $\begin{array}{c}\text { T- } \\
\text { ratio }\end{array}$ & $\begin{array}{c}\text { Level of } \\
\text { significance }\end{array}$ \\
\hline $\begin{array}{c}\text { Home } \\
\text { Environment }\end{array}$ & High AA & 43 & 217.48 & 15.64 & 3.52 & 5.56 & .05 \\
\hline
\end{tabular}

Table Value of $72 \mathrm{df}$ at. 05 level $=1.96$ and. 01 level $=2.58$

It is revealed from the Table- 3 that the mean score of high and low academic achiever visually students on home environment are 217.48, 197.89 with S.D 54.64, 48.46 respectively. The t-ratio came out to be 5.56 which is significant at. 01 level of significance. That means there is significant difference between high and low academic achiever visually impairment students on home environment. However, the mean score of high academic achiever tribal students are higher than the low academic achievers. It implies that the students those are belonging better home environment has better academic achievement.

\section{Discussion of the result}

There is a significant difference between high and low academically achiever students on Home Environment. However the students those were belonging to better home environment had more academic achievement. Findings of the present study reveal that there is significant positive relationship between academic achievement and Home Environment of tribal students. It is suggested that parents should get appropriate guidance and counseling about dealing with the tribal students to develop academic achievement. Special need children should be identified as early as possible by parents in the home and later by teacher in the schools for better education of the disabled students. The tribal students need conducive home environment for their proper development especially academic development.

\section{References}

1. Aggarwal JC. Special Education in India, New Delhi: Concept Publishing Company, 1992, 232-274

2. Cramer H, Carln J. Family Based Short Breaks for Disabled Children, British Journal of Social World. 2007; 38(6):1060-1075

3. Deforges C. The impact of parental involvement, parental support and family education on pupil achievement and adjustment, Research Report, 2003.

4. Jeynes William H. Parental involvement and student achievement. A Meta-Analysis Science. 2005; 331:6023.

5. Kamalauva B Bailur. Influence of relations of family, peers and pressures of PUC IInd year students on their adjustment and academic performance, A thesis, Dharwad Uni. Dharwad, 2006.

6. Mandlakayise G Manda. Home Environment and pupils academic achievement. Master Dissertation, University of Zuluand, 1997.

7. Martinez, Paul, E. The home environment and academic achievement: There is a correlation. Journal of Educational Psychology. 1981; 96(2):17-21.

8. Parua RK, Sohta R. Socio Economic Status as a Correlate of Vocational Interests of Tribal Secondary School Students. Maa Omwati Journal of Education. 2010 2(1):24-33.

9. Sharma S. Feeling of insecurity among parents of disable children, M.Ed Dissertation, Chandigarh: Punjab University, 2006. 